Nig. J. Biotech. Vol. 38 (1) : 55-60 (June 2021)

ISSN: 01891731

Available online at

http://www.ajol.info/index.php/njb/index

and www.biotechsocietynigeria.org

DOI: https://dx.doi.org/10.4314/njb.v38i1.6

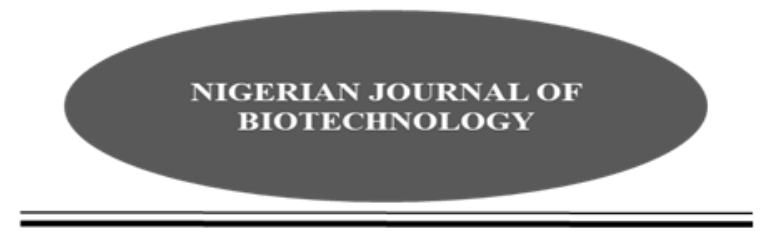

\title{
Effect of Wrapping Materials on the Microbial Quality of some Street Vended Ready- to - Eat Rice
}

\author{
*Ojesola, C. $\mathbf{O}^{1}$., Afolabi, O. $\mathbf{R}^{2}$. and Oloyede, A. $\mathbf{R}^{2}$. \\ ${ }^{1}$ Biotechnology Centre, Federal University of Agriculture, Abeokuta, Ogun State, Nigeria. \\ ${ }^{2}$ Microbiology Department, Federal University of Agriculture, Abeokuta, Ogun State, Nigeria.
}

\begin{abstract}
In many parts of Africa especially in Nigeria, ready-to-eat rice is commonly sold in several locations within the big cities and villages. In this study, one hundred samples of ready-to-eat rice were analyzed in some selected areas in Abeokuta, Ogun State, Nigeria. The effects of wrapping materials on the microbial quality of the rice samples were determined from seven different locations. The total bacterial counts ranged from 5.66 to $7.30 \log 10 \mathrm{cfu} / \mathrm{g}$, total coliform counts ranged from 5.07 to $7.33 \mathrm{log} 10 \mathrm{cfu} / \mathrm{g}$ and total fungal counts ranged from 5.19 to $6.03 \log 10 \mathrm{cfu} / \mathrm{g}$. The b acterial species isolated from these samples were Bacillus subtilis, Klebsiella pneumonia and Staphylococcus aureus while the fungal species isolated include Aspergillus fumigatus, Mucor spp., and Penicillium sp. Factors such as improper storage as well as handling of the wrapping-materials of the food coupled with the attitude and practices of the vendors are likely to be responsible for the growth of these microorganisms. It was also discovered that improper cooking may contribute to microbial growth. Provision and enforcement of strict hygienic practices would go a long way in improving the quality of the ready-to-eat foods.
\end{abstract}

Keywords: Ready-to-eat-rice, wrapping materials, microbial quality.

*Corresponding author: idit01@yahoo.com Tel: +2348027320685

\section{Introduction}

The Food and Agriculture Organization (FAO, 2009) defines street foods as "ready-to-eat foods and beverages prepared and sold in streets and other similar public places". Street foods are exposed to abundant microorganisms during preparation, transportation, preservation, and distribution of foods as well as the personal hygiene of food vendors (Oluwafemi et al., 2013). In recent years, food-borne pathogens become an important public health problem worldwide, and their impact on health (significant morbidity and mortality rate) and economy is increasingly recognized (Hemalata and Virupakshaiah, (2016); Zhao et al., (2014); Akbar and Kumar-
Anal, (2011); Ayano et al., (2015); Bedasa et al., 2018).

Street foods have become popular, not only as a source of convenient and affordable food, but also as a main source of livelihood (Dexter and Alex, 2014). People who depend on such foods are often more interested in its convenience rather than its safety, quality and hygiene (Barro et al.,2002a ; 2002b, Collins 1997; Mensah et al.,2002).

However, street food vendors overlook the importance of the safety and nutritional quality of the food they serve, which can cause food-related diseases, even poisoning and death to customers (Dexter and Alex, 2014). Safe food is a 
fundamental human right despite the fact that many foods frequently are contaminated with naturally occurring pathogenic microorganisms. These organisms cannot be detected organoleptically (but can cause diseases including death, especially if the way they are conserved during exposition for sale provides a condition for those microorganisms to grow and reach significant levels of contamination (WHO, 2000 ; Oranusi et al.,2013)

As expected, the nutritional needs of the consumers should be met via the consumption of street food; it is also necessary to ensure its safety from contaminants and microorganisms (Monday et al., 2014). Vendors of ready to eat rice are available everywhere, probably because with minimal cost the business can be established. The origin of food packaging can be said to be as old as civilization. It is an integral part of food processing and entails the use of some materials in the packaging of foods (Ayo, 2003.) Packaging is an important descriptive area of food technology, as it concerns the preservation and protection of all types of food materials from microbial spoilage and oxidation. It also extends the shelf-life characteristics of products (Komolafe, 2005). However, packaging materials have been known to be a possible source of microbial contamination of food (Frazier and Westhoff, 1988). In Nigeria, traditional wrapping materials such as sweet prayer plant leaves ( Thaumatococcus danielli), banana leaves, cocoyam leaves and plantain leaves have gained ground for a long time (Peter- Ikechukwu, 2015). The use of synthetic materials such as tin can, aluminum foil, cellophane paper, glass, plastics etc. were invented with civilization to make packaging easier and presentable (Onweluzo and Eillita, 2003).

These wrapping materials are usually meant for containment with little or no attention paid to the safety of the consumers. The hygienic state of the wrapping materials and its appropriateness for the food products are not considered in its selection (Adejumo and Ola, 2008). Therefore there is a need to assess the effect of these wrapping materials on the microbial quality of ready-to-eat rice, as most of these vendors exhibit poor hygienic habits in the storage and handling of the wrapping materials.

\section{Materials and Methods}

\section{Sample collection}

Ready-to-eat rice samples scooped into different packing materials (leaves, foam plates and polyethylene bags) were collected from vendors at different locations in Abeokuta, Ogun State, Nigeria. From each vendor, samples were also collected in sterile containers to serve as control. The samples were taken to the laboratory for analysis.

\section{Microbial Analysis}

One gram of each sample was weighed separately and serially diluted $\left(10^{-5}\right)$ before being subjected to total plate, coliform and fungal counts using Nutrient agar (LAB M), MacConkey agar (LAB M) and Potato dextrose agar (LAB M) plates. All media were prepared according to the manufacturer's specification. After inoculation, the Nutrient and MacConkey agar plates were incubated at $37^{\circ} \mathrm{C}$ while potato dextrose agar plates were incubated at $25^{\circ} \mathrm{C}$.

\section{Characterization and Identification of Isolates}

Distinct colonies on Nutrient and MacConkey agar plates were characterized by morphological and biochemical methods and identified using Bergey's Manual of Systematic Bacteriology (Holt et al., 1994). Pure colonies on Potato dextrose agar plates were examined under the microscope and identified using lactophenol cotton blue stain.

\section{Molecular Characterization}

Chromosomal DNA of the bacteria isolates were isolated using CTAB (CetylTrimethyl Ammonium Bromide) method, as described by Alexander Worden (2009). Polymerase chain reaction amplified the 16SrRNA and the genes were sequenced. Sequence assembly and alignment were carried out, followed by searching the homology in the Genbank database of National Centre for Biotechnology Information (NCBI) using BLASTn tool to identify the isolates.

\section{Results and Discussion}

The total microbial counts $(\log 10 \mathrm{cfu} / \mathrm{g})$ of readyto-eat (RTE) rice in different wrapping materials are shown in Table 1.These ranged from 5.07 to $7.33 \log 10 \mathrm{cfu} / \mathrm{g}$. Total bacterial counts ranged between 5.66 to 7.30 , total coliform count ranged from 5.07 to 7.33 and the total fungal count ranged between 5.19 and 6.03. Ready-to-eat rice 
samples in leaves had highest bacterial and coliform counts, while RTE rice samples in polyethylene bags had the highest fungal counts. The lowest counts were found in RTE rice in sterile containers.

Biochemical and morphological characteristics of the bacterial isolates from ready-to- eat rice in different wrapping materials sold in selected areas in Abeokuta are summarized in Table 2 while Table 3 shows the molecular characterization of the bacterial strains with the percentage match; the organisms were identified to be Staphylococcus aureus, Klebsiella pneumoniae and Bacillus cereus.

Table 1: Total Microbial Counts of Ready-to- eat rice packaged with different materials

\begin{tabular}{|c|c|c|c|c|c|c|c|c|c|c|}
\hline \multirow[t]{2}{*}{$\begin{array}{l}\text { Suspected } \\
\text { organism }\end{array}$} & \multicolumn{7}{|c|}{ Biochemical characteristics } & \multicolumn{3}{|c|}{$\begin{array}{l}\text { Morphological } \\
\text { characteristics }\end{array}$} \\
\hline & Catalase & Coagulase & Indole & Citrate & Urease & $\begin{array}{l}\text { Methyl } \\
\text { Red }\end{array}$ & $\begin{array}{l}\text { Voges - } \\
\text { Proskauer }\end{array}$ & $\begin{array}{l}\text { Size } \\
(\mathrm{mm})\end{array}$ & Shape & $\begin{array}{l}\text { Gram } \\
\text { reation }\end{array}$ \\
\hline Bacillus subtilis & + & - & - & - & - & + & - & $3-5$ & Irregular & $\begin{array}{l}+\mathrm{ve} \\
\text { rods }\end{array}$ \\
\hline $\begin{array}{l}\text { Klebsiella } \\
\text { pneumoniae }\end{array}$ & + & - & - & + & + & - & + & $3-4$ & Round & $\begin{array}{l}\text {-ve } \\
\text { rods }\end{array}$ \\
\hline $\begin{array}{l}\text { Staphylococcus } \\
\text { aureus }\end{array}$ & + & + & - & - & - & - & + & $2-3$ & Round & $\begin{array}{l}+ \text { cocci } \\
\text { in } \\
\text { clusters }\end{array}$ \\
\hline
\end{tabular}

Table 2: Biochemical and Morphological characteristics of bacterial isolates from street vended ready-toeat rice wrapped with different materials, sold in Abeokuta

\begin{tabular}{|l|l|l|l|l|}
\hline $\begin{array}{l}\text { Packaging } \\
\text { material }\end{array}$ & $\begin{array}{l}\text { No. of } \\
\text { samples }\end{array}$ & $\begin{array}{l}\text { Total bacterial } \\
\text { count }(\mathbf{l o g} \mathbf{1 0} \text { cfu/g) }\end{array}$ & $\begin{array}{l}\text { Total coliform } \\
\text { count }(\mathbf{l o g} 10 \\
\text { cfu/g) }\end{array}$ & $\begin{array}{l}\text { Total fungal } \\
\text { count }(\mathbf{l o g 1 0} \\
\text { cfu/g) }\end{array}$ \\
\hline Leaves & 16 & 7.30 & 7.33 & 5.70 \\
\hline Foam plates & 28 & 6.19 & 5.36 & 5.87 \\
\hline $\begin{array}{l}\text { Polyethylene } \\
\text { bags }\end{array}$ & 28 & 5.68 & 6.54 & 6.03 \\
\hline $\begin{array}{l}\text { Sterile } \\
\text { containers }\end{array}$ & 28 & 5.66 & 5.07 & 5.19 \\
\hline
\end{tabular}

Table 3: Molecular Characterization of the bacterial isolates

\begin{tabular}{|l|l|l|}
\hline Isolate & \% match & Accession number \\
\hline $\begin{array}{l}\text { Staphylococcus aureus sub sp } \\
\text { aureus NCTC 8325 (3) }\end{array}$ & $71 \%$ & NC 007795.1 \\
\hline $\begin{array}{l}\text { Klebsiella pneumoniae sub sp } \\
\text { pneumoniae HS 11286 (4) }\end{array}$ & $91 \%$ & NC 016845.1 \\
\hline $\begin{array}{l}\text { Bacillus cereus Rock 4-18 (5) } \\
\text { Bacillus cereus AH 621 (6) }\end{array}$ & $76 \%$ & NZ CM000735.1 \\
\hline $\begin{array}{l}\text { Klebsiella pneumoniae sub sp } \\
\text { pneumoniae HS 11286 (7) }\end{array}$ & $95 \%$ & NC CM 000719.1 \\
\hline $\begin{array}{l}\text { Klebsiella pneumoniae sub sp } \\
\text { pneumoniae HS 11286 (8) }\end{array}$ & $90 \%$ & NC 016845.1 \\
\hline
\end{tabular}




\begin{tabular}{l|l|l}
$\begin{array}{l}\text { Klebsiella pneumoniae sub sp } \\
\text { pneumoniae HS } 11286(11)\end{array}$ & NC 016839.1 \\
$\begin{array}{l}\text { Klebsiella pneumoniae sub sp } \\
\text { pneumoniae HS } 11286(12)\end{array}$ & $77 \%$ & NC 016845.1 \\
\hline
\end{tabular}

Figure 1 shows the amplified 16S rRNA of the bacterial isolates. Characteristics of fungal isolates are summarized in Table 4 while Table 5 shows the incidence of microorganisms in readyto- eat rice in different wrapping materials sold in
Abeokuta. Three bacteria species isolated are Bacillus subtilis, Klebsiella pneumoniae, and Staphylococcus aureus while the fungi isolated were Aspergillus fumigatus, Mucor sp. and Penicillium sp.

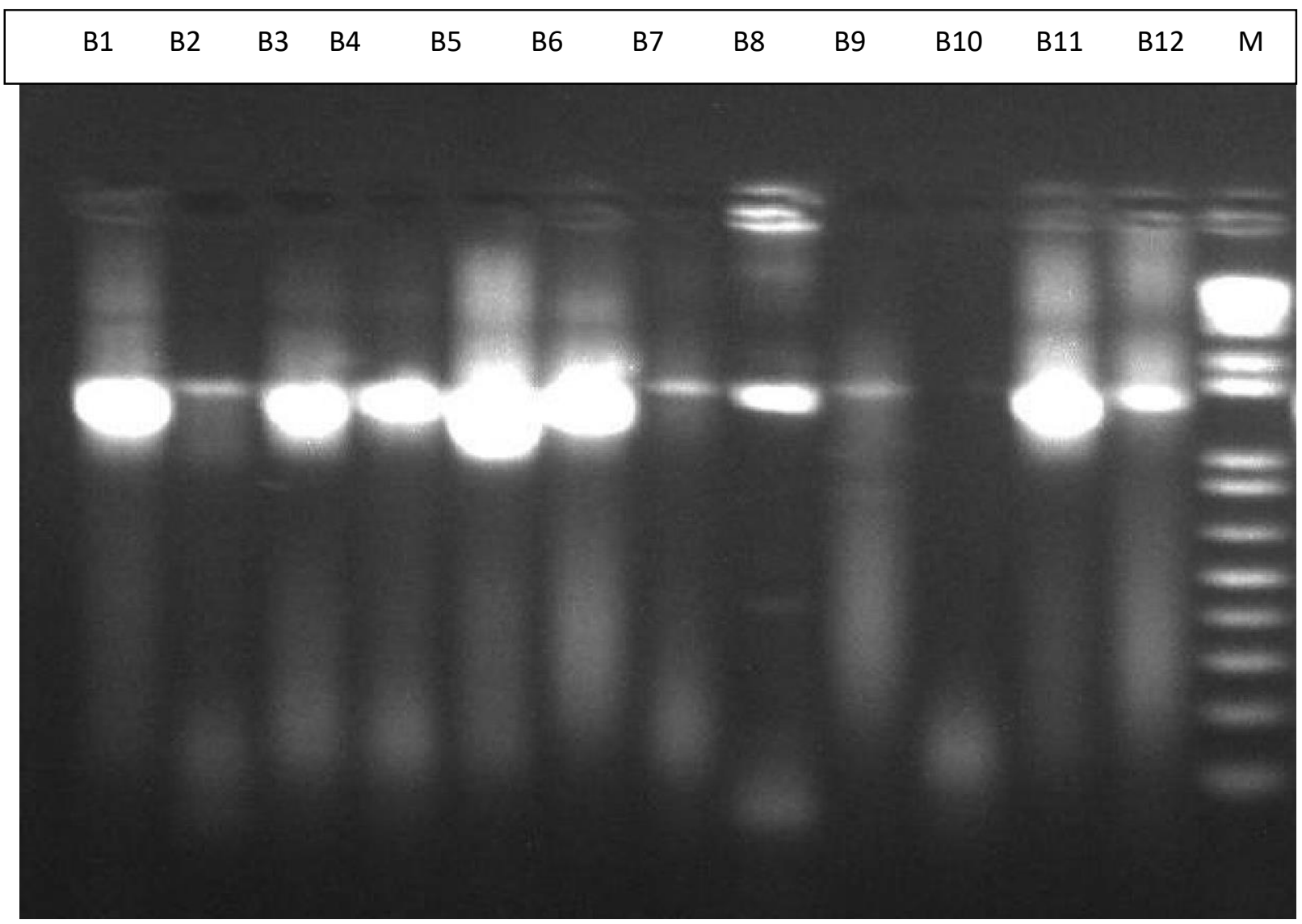

Figure 1: Amplified 16SrRNA of bacterial isolates

Table 4: Characteristics of fungal isolates from street vended ready-to-eat rice in different wrapping materials, sold in Abeokuta

\begin{tabular}{|l|l|l|}
\hline Organism & Macroscopy & Microscopy \\
\hline Aspergillus fumigatus & Green filamentous colonies & Smooth walled conidiophores \\
\hline Mucorsp & Cotton-like colonies & Hyphae without rhizoids \\
\hline Penicillium sp & Grey-white colonies & Pyriform conidiophores \\
\hline
\end{tabular}


Ojesola et al. / Nig. J. Biotech. Vol. 38 Num. 1 : 55-60 (June 2021)

Table 5: Incidence of microorganisms in ready-to-eat rice in different wrapping materials, sold in Abeokuta

\begin{tabular}{|l|l|}
\hline Wrapping material & Microorganisms \\
\hline Foam plates & $\begin{array}{l}\text { Penicillium sp., Bacillus sp., Klebsiella } \\
\text { pneumoniae, Aspergillus fumigatus }\end{array}$ \\
\hline Polyethylene bags & $\begin{array}{l}\text { Penicillium sp., Bacillus sp.,Mucor sp., } \\
\text { Staphylococcus aureus, Klebsiella pneumoniae. }\end{array}$ \\
\hline Leaves & $\begin{array}{l}\text { Penillium sp., Bacillus sp., Klebsiella } \\
\text { pneumoniae. } \\
\text { Aspergillus fumigatus, Bacillus sp.,Mucor } \\
\text { sp., Penicillium sp.,Staphylococcus aureus, Bacillus } \\
\text { subtilis, Klebsiella pneumoniae. }\end{array}$ \\
\hline
\end{tabular}

All the isolated organisms are of public health significance and their presence in food indicates that the food is highly contaminated and not fit for human consumption. Total microbial counts ranged from $5.07 \log 10 \mathrm{cfu} / \mathrm{g}$ to $7.33 \log 10 \mathrm{cfu} / \mathrm{g}$, which is higher than the acceptable levels $(<5 \log 10 \mathrm{cfu} / \mathrm{g})$, is an indication that RTE rice sold in some areas in Abeokuta are highly contaminated with microorganisms, and the results are in agreement with the results of Felgo and Saki (2012) and Oranusi et al. (2012) who found ready-to-eat foods to be contaminated beyond acceptable levels. Though Escherichia coli (an indicator organism) was not isolated in any of the samples, other potential pathogens such as Klebsiella pneumoniae and Staphylococcus aureus as well as other opportunistic microorganisms like Mucor sp., Aspergillus fumigatus and Penicillium sp. could render the foods unsatisfactory for human consumption. The presence of these organisms in the food samples examined further indicates improper handling and possible cross-contamination.

The contamination of the RTE rice could be attributed to the attitude and practices of the vendors regarding cooking and packaging, with little or no attention being paid to good manufacturing practice during packaging. Some vendors have the habit of cleaning the wrapping materials with their cloths; some usually blow air into these materials in an attempt to open or blow off dust; thereby unintentionally introducing microorganisms into them. The wrapping materials were not properly stored, and some vendors always keep the RTE rice in foodwarmers with white polyethylene spreads, which had turned brownish over time due to continual usage without changing. Some vendors held serving spoons with their thumbs directly inside the spoons during serving. The ways in which the ready- to- eat rice samples were displayed and the environment at which the foods were being dispensed could also be responsible.

\section{Conclusion and Recommendation}

In conclusion, the study revealed that the wrapping materials used for packaging of RTE rice have great impact on the microbial quality of street-vended RTE rice sold in Abeokuta as those packaged with leaves, foam plates and polythene bags were highly contaminated with microorganisms when compared to those collected with sterile containers. Hence, there is a need for Government, particularly at the local levels, to enforce compliance with strict hygienic practices in the preparation and handling of street-vended foods and the wrapping materials used for packaging. These foods are now part of many people's daily lives and negligence on the part of the Government could put people's lives and that of the unborn in jeopardy.

\section{References}

Adejumo, B.A. and Ola, F.A. (2008).The appraisal of local food packaging materials in Nigeria. Cont.J.Eng.Sci.3:13 - 20.

Akbar, A. and Kumar-Anal, K. A. (2011). Food safety concerns and food-borne pathogens, Salmonella, Escherichia coli and Campylobacter. FUUAST j. biol.1 (1):5-17. 
Ayana, Z., Yohannis, M. and Abera, Z. (2015). Food-borne bacterial diseases in Ethiopia. J. Acad. Nutr. Diet. 4(1): 62-76.

Ayo, J. A. (2003). Food packaging: Origin, Trend, Principles and Applications. AMANA Publishers, Nigeria. Pp.1.

Barro, N., Ouattara, C.A.T., Nikiema, A.P., Quattara, A.S. and Traore, A.S. (2002a). Evaluation de la qualitemicrobiologique de quelques aliments de rue dans la ville Ouagadougou, Burkina Faso. Cah. Santé, 12: 369-74.

Barro, N., Ouattara, C.A.T., Nikiema, P., Quattara, A.S. and Traore, A.S. (2002b). Evaluation de l'hygieneet de la qualitemicrobiologique de quelques aliments rue et les caracteristiquse des consommateursdans les villes de Ouagadougou et de Bobo-Dioulasso (Burkina Faso). Rev. Sci. Tec. Sci. Sante, 25: 721.

Bedasa, S. Shiferaw, D. Abraha, A. and Moges, T. (2018). Occurrence and antimicrobial susceptibility profile of Escherichia coli O157:H7 from food of animal origin in Bishoftu town, Central Ethiopia. Int. J. Food Contam. 5(1):1-8.

Collins, J.E. (1997). Impact of changing consumer lifestyles on the emergence/reemergence of foodborne pathogens. Emerg. Infect. Dis. 3:471479.

Dexter, R., Buted, Alex, P. and Y. lagan. (2014).Street Food Preparation Practices. APJEAS. 1 (2)

F.A.O. (2009).Good hygienic practices in the preparation and sale of street food in Africa. Rome, Italy.

Felgo, P. and Saki, K. (2012).Bacterial contamination of street food in Kumasi, Ghana. J. Medical Biomed. Sci. 1(1):1-8.

Frazier, W.C. and Westhoff, D.C. (1988): "Food Microbiology" (4th Edition). New York. McGraw Hill Book Company. p.185.

Hemalata, V. B. and Virupakshaiah, D. B. M. (2016). Isolation and identification of food borne pathogens from spoiled food samples. Int. J. Curr. Microbio.I Appl. Sci. 5 (6):1017-1025.

Holt, J.G., Krieg, N.R., Sneath, P.H.A., Stanley, J.T. and Williams, S.T. (1994). .Bergey's Manual of Determinative Bacteriology, 9th edition. Beltimore, M.D. Williams and Wilkins (eds).

Komolafe, E.A. (2005). Food Packaging. Biotidara PublisherEringbo, Akure. pp 47- 51. 7

Mensah, P., Yeboah-Manu, D., Owusu-Darko, K. and Ablodey, A. (2002). Street foods in Accra, Ghana: How safe are they? Bulletin of World Health Organization. 80(7):546-554.

Monday, I.E., Francis, J.I. and Mohammed, S.U. (2014). Microbial quality of ready-to-eat- foods (rice and moimoi) sold by food vendors in Federal Polytechnic Bali, Taraba State, Nigeria.. J. Environ. Sci. Technol. 8 (2): 145-149.

Oluwafemi, .F, Akisanya, E., Odeniyi, K.., Salami, W. and Sharomi, T. (2013). Microbial Quality of StreetVended Foods- Ready -To Eat Vegetables in Some Nigeria Cities. AJOL 16: (3).

Onweluzo, J.C. and Eillita, M. (2003) .Surveying Mucuna utilization as a food in Enugu and Kogi State of Nigeria. Trop. Subtrop. Agroecosystems. I.1: 213-225.

Oranusi, S.U. (2013). Microbial Quality Assessment of Foods sold in Student's Cafeterias. Int. Res. J. Microbiol. 3(1) 1-.7

Oranusi, U.S. and Baride, W. (2012). A study of microbial safety of ready-to-eat foods vended on highways; Onitsha-Owerri, South East Nigeria. Int. J. Microbiol. Res. 3(2): 066-071.

Peter- Ikechukwu, A.I. (2015). Effect of wrapping material on chemical and microbiological qualities of Fermented melon seed (Citrullus vulgaris $\mathrm{L}$. Series) Anal. Chem. 15(2) 74- 82.

World Health Organization. (2000). Food borne diseases; A focus for health education. 53rd world health assembly, Geneva. 
Ojesola et al. / Nig. J. Biotech. Vol. 38 Num. 1 : 55-60 (June 2021)

Zhao, X., Lin, C., Wang, J. and Oh, D. (2014). Advances in rapid detection methods for foodborne pathogens. J. Microbiol. Biotechnol. 24 (3):297-312. 